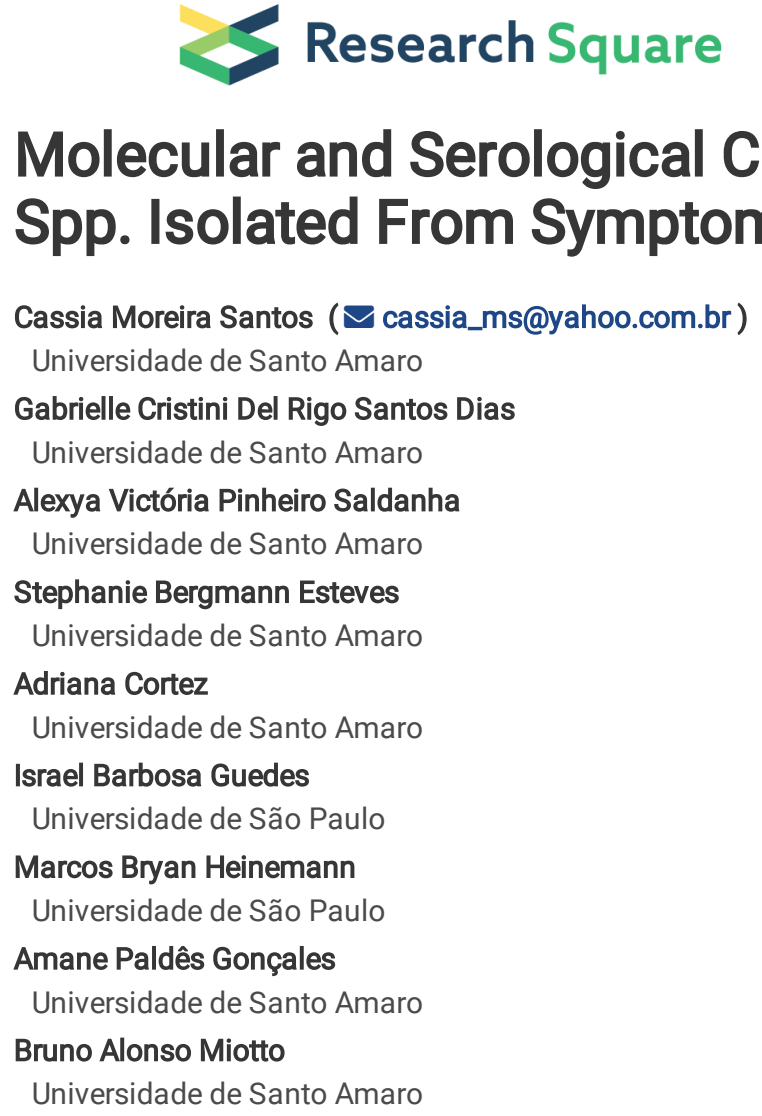

\title{
Molecular and Serological Characterization of Pathogenic Leptospira Spp. Isolated From Symptomatic Dogs in a Highly Endemic Area, Brazil
}




\section{Abstract}

Background: Leptospirosis is an endemic zoonosis in Brazil, with great impact in human and animal health. Although dogs are frequently infected by pathogenic Leptospira, the current epidemiological understanding of canine leptospirosis is mainly based on serological tests that predict the infecting serogroup/serovar. Thus, the present study aimed at identifying the causative agent for severe cases of canine leptospirosis in a highly endemic area through the isolation and characterization of the isolated strains.

Results: Urine, serum and blood samples were collected from 31 dogs with suspected acute leptospirosis treated at the Veterinary Hospital Service of Santo Amaro University between 2018 and 2019. Acute infection was confirmed in 17 dogs (54.8\%) by the associated use of Polymerase Chain Reaction (PCR), Microscopic Agglutination (MAT) and bacteriological culture. Eleven dogs (35.5\%) had titers $\geq 800$, with the most frequent serogroups being Autumnalis and Icterohaemorrhagiae $(n=4$ each) and Canicola $(n=2)$. Leptospires were recovered from four dogs, and Multilocus Sequence Analysis (MLSA) revealed infection caused by $L$. interrogans, which were further characterized as serogroups Canicola ( $\mathrm{n}=1$ ) and Icterohaemorrhagiae $(n=3)$.

Conclusion: The identification of circulating strains in poverty-stricken locations with humans living in rural-urban interfaces may assist local authorities to implement effective prevention policies. The identity of the isolates and serological pattern of MAT titers found among the suspected dogs suggest that dogs are highly exposed to the serogroup Icterohaemorrhagiae, also indicating possible circulation of serogroups not yet isolated in Brazil, notably serogroup Autumnalis.

\section{Background}

Leptospirosis is a bacterial zoonotic disease of worldwide distribution, potentially lethal and capable of causing epidemic outbreaks in human and domestic animal populations $(1,2)$. Dogs can act as an important source of infection for humans and other mammals, as they are able to eliminate the pathogen into the environment via urine and other body fluids (3). Therefore, the identification of infected individuals is essential to support the implementation of preventive measures, with strong One Health impact.

Canine leptospirosis has been widely reported (4), and infection in dogs can lead to a wide variety of clinical manifestations, ranging from asymptomatic infections or mild febrile illness to severe multisystem organ failure (5). Laboratory findings are mostly inconclusive, and the definitive diagnosis is still based on confirmatory tests for the direct or indirect identification of the pathogen (6), such as dark-field microscopy, Polymerase Chain Reaction (PCR), bacterial culture and serum antibody titration.

The Microscopic Agglutination Test (MAT) has been widely used for the serodiagnosis of acute disease in dogs, and it is considered the gold standard to confirm leptospiral infection (6). However, the impossibility to identify the infecting serovar and its inability to differentiate vaccineinduced titers from natural exposure have restricted its use in a clinical setting (7). Moreover, the evaluation of a single sample may fail to detect antibodies during the initial phase of the disease, and it is often necessary to also test sera obtained in the convalescent phase to reveal seroconversion, which is often not possible due to the high lethality of the disease.

The PCR technique, on the other hand, has been successfully used to confirm infection at the early stages of the disease (8, 9), showing to be also a useful tool to identify infecting species by further DNA sequencing of PCR amplicons (10). Yet, PCR may not provide reliable results during the convalescent phase of the disease (5) and its use as a single diagnostic strategy is also limited.

Since the exact time of infection at clinical presentation is typically unknown, and as both MAT and PCR diagnostic sensitivity and specificity are highly dependent on the stage of the disease, the association of both tests paired with careful clinical and biochemical/hematological evaluation is highly recommended to increase the chances for a definitive diagnosis and further therapeutic success (11). Yet, despite the benefits of using multiple diagnostic strategies, only the isolation of leptospires and subsequent characterization of the isolates can provide full identification of the infecting strain (6).

Acute disease in dogs is typically associated to serogroups Icterohaemorrhagiae, Canicola and Gryppothyphosa (6), however accidental infection caused by a broader spectrum of serogroups have been described, such as Pomona (12), Australis (10), Autumnalis (13), Hebdomadis (13), Bratislava (14), Bataviae (15), Sejroe (10) and Ballum (16). The establishment of a panel of leptospiral strains circulating among local canine populations remains the only and main strategy to subsidize the development and commercialization of polyvalent vaccines that can effectively provide protection for susceptible canine populations, and the wide variety of infecting serovars so far described evidences the importance and the challenges of producing vaccines containing representative leptospires circulating locally.

Unfortunately, isolation is challenging due the fastidious growth of the pathogen and the frequent contamination of culture media (6). Furthermore, culturing is frequently restricted by the early institution of antimicrobial therapy, which is usually implemented immediately after the disease is suspected (11), and the low sensitivity of the technique undermines clinicians to even consider culturing as a diagnostic strategy during the clinical procedure. 
Even in face of the importance of characterizing leptospires for further vaccine development, few studies tackling the causative agent of canine leptospirosis have been conducted in Brazil $(5,17-21)$ and the characterization of leptospires isolated from dogs with clinical suspicion of the disease remains poorly documented.

Dogs may act as important sentinels to investigate serovars circulating in certain regions and surveillance of leptospiral strains causing clinical disease in dogs should be further explored, especially in locations with rural-urban interfaces, where contact with wildlife fauna predisposes infection caused by unusual leptospiral strains.

By using an integrative approach, which included clinical/laboratorial evaluation and serological and molecular methods, the present study aims to provide characterization of the isolated leptospires from dogs with acute leptospirosis treated at the Veterinary Service of the University Santo Amaro (UNISA), a hospital service that provides animal care for low income communities located at the most endemic region for human leptospirosis in São Paulo city, Brazil.

\section{Materials And Method 2.1. Study area}

The veterinary hospital of the Santo Amaro University is located at the southern region of the city of São Paulo (Capela do Socorro sub-prefecture), a region composed of approximately 173,180 households, of which 31,896 have no access to sewage system. The region has $594,930 \mathrm{~m}^{2}$ of green area, characterized by extensive rural-urban interface bathed by two important large river dams (22).

\subsection{Experiment design and inclusion criteria}

Urine and whole blood samples were collected from 31 dogs with clinical suspicion of leptospirosis treated at the Veterinary Hospital of Santo Amaro University (HOVET-UNISA), between September 2018 and November 2019. Inclusion criteria consisted of dogs presenting blood urea nitrogen and creatinine levels above the reference values $(64.2 \mathrm{mg} / \mathrm{dL}$ and $1.4 \mathrm{mg} / \mathrm{dL}$, respectively) or jaundice, that also presented two or more clinical manifestations suggestive of acute leptospirosis, including hemorrhagic disorders, fever, vomiting, prostration, hyporexia/anorexia and olyguria/anuria. Vaccination status was also investigated during physical examination, and dogs with history of polyuria, polydipsia and weight loss one month prior to the clinical presentation were not included to rule out possible chronic kidney disease.

Blood and urine samples were used for bacterial culturing and DNA detection of leptospires by PCR. Serum samples were destined for the microscopic agglutination test (MAT) and serum biochemistry analyses. The samples taken at first medical assistance were collected between clinical/laboratorial suspicion of the disease and the establishment of antimicrobial therapy.

The dogs were prospectively monitored after the first evaluation, and revaluations included serum detection of anti-Leptospira antibodies to detect possible seroconversion. Revaluation were carried out up to 14 days after the first evaluation, with no systematized sampling scheme.

\subsection{Diagnostic criteria}

Dogs that had $\geq 800$ titers detected by MAT, positive PCR and/or bacterial isolation were considered acutely infected by leptospires. Dogs that were revaluated and presented seroconversion characterized by a 4-fold increase in antibody titration were also considered actively infected, as well as those that presented no antibodies at the first evaluation but had titres equal to 100 at the second evaluation.

\subsection{Collection and storage of samples}

Blood samples were collected by venipuncture of the jugular or cephalic veins into EDTA tubes and haematological analyses were performed immediately after collection. Part of the blood samples were drawn into anticoagulant-free tubes to obtain blood sera. Urine samples were collected by cystocentesis to minimize bacterial contamination and increase the chances for culturing leptospires in selective medium. The blood and urine aliquots destined for bacterial culturing were processed immediately after collection. Urine, blood and serum samples destined to PCR, MAT and serum biochemistry analyses were stored at $-20^{\circ} \mathrm{C}$ until processing.

\subsection{Microscopic agglutination test}

The microscopic agglutination test was performed as described by Faine et al. (1999). The serum of the suspected animals was tested against a panel of 20 serogroups including 24 serovars: Australis, Bratislava, Guaricura, Autumnalis, Butembo, Castellonis, Bataviae, Canicola, Whitcombi, Cynopteri, Gryppotyphosa, Hebdomadis, Copenhageni, Icterohaemorrhagiae, Javanica, Panama, Pomona, Pyrogenes, Hardjo (Hardopratijno), Hardjo (Hardjobovis), Shermani, Tarassovi, Pomona and Sentot. The cutoff for a positive agglutination reaction was defined as a titer $\geq 100$, however only dogs with $\geq 800$ titers or presenting seroconversion were considered to have acute leptospirosis. For each positive sample, the most probable infecting serogroup was the one presenting the highest titers.

\subsection{Leptospira spp. culturing}


For Leptospira isolation, $500 \mu \mathrm{L}$ of urine and whole blood were diluted in sterile Sorensen buffer solution at 1:10 and 1:100, and further seeded into tubes containing Fletcher and EMJH medium (Difco Laboratories, Franklin Lakes, NJ, USA). The tubes were incubated at $28^{\circ} \mathrm{C}$ and observed weekly for six weeks to check the superficial growth ring (Dinger's zone). The presence of leptospires was confirmed by dark-field microscopy visualization.

\subsection{DNA extraction and PCR amplification}

The urine samples were centrifuged at $13,000 x$ for 15 minutes at $20^{\circ} \mathrm{C}$, and the sediment was resuspended in $300 \mu \mathrm{L}$ of sterile Tris-EDTA solution after discarding the supernatant. DNA was extracted from $200 \mu \mathrm{L}$ of blood or resuspended urine sediment using PureLink $B$ Genomic DNA Mini Kit (Invitrogen, Thermo Fisher Scientific Inc., Carlsbad, CA, US) following the manufacturer's recommendations. DNA amplification of pathogenic leptospires was carried out a qualitative assays targeting the $331 \mathrm{bp}$ fragment of the $16 \mathrm{~S}$ rRNA gene using primers and amplification conditions described by Mérien et al (1992).

The amplified products were separated by electrophoresis on a 1.5\% agarose gel stained with SYBR Safe DNA (Invitrogen, Thermo Fisher Scientific Inc., Carlsbad, CA, US) and analysed under ultraviolet transillumination. The amplicons presenting a single band were purified using $2 \mu \mathrm{L}$ ExoSap-IT (Thermo Fisher Scientific Inc., Carlsbad, CA, EUA) and amplification showing multiple gel bands were purified using the Wizard $®$ SV gel and PCR Clean-up System kit (Promega Corporation) according to the manufacturer's specifications.

\subsection{Characterization of the isolates and $P C R$ amplicons}

\subsubsection{Serogrouping}

The serogroups of the isolates were determined by MAT as previously described (25) using a panel of rabbit anti-sera for 23 polyclonal antisera against Leptospira spp., which represented 17 distinct serogroups: Australis, Autumnalis, Ballum, Bataviae, Canicola, Cynopteri, Grippotyphosa, Hebdomadis, Icterohaemorrhagiae, Mini, Panama, Pyrogenes, Pomona, Sarmin, Sejroe, Shermani and Tarassovi. The highest titer for a particular antiserum was used as criteria to identify the presumptive serogroup.

\subsubsection{DNA Sequencing and phylogenetic analysis}

The 16S rRNA amplicons the positive PCR samples (including samples that leptospires could be also isolated) were sequenced using the BigDye Terminator Cycle Sequencing kit (Life Technologies ${ }^{\circledR}$ ) for further sequencing analysis. The amplicons were sequenced in an $\mathrm{ABI} 7500 \mathrm{Genetic}$ Analyzer (Life Technologies ${ }^{\circledR}$, Waltham, MA, US). Quality analysis of the generated sequences was performed using the PHRED platform (26). The readable sequences were edited using the BIOEDIT 7.0.9 editor (Hall, 1999 - Ibis Biosciences, Carlsbad, CA, US) and compared with reference sequences retrieved from GenBank using the BLAST tool (http://www.ncbi.nlm.nih.gov/BLAST/).

Phylogenetic trees were built using software Mega software version 7.0 (27) The generated trees were constructed by the Neighbor-Joining method using the Tamura 3-parameter model, with bootstrap values of 1,000 repetitions.

\subsubsection{Multiple loci VNTR analysis}

Multiple locus variable-number tandem repeat analysis (MLVA) was performed according to Salaün et al. (2006) using three discriminatory markers usually presented by Leptospira interrogans (VNTR loci 4, 7 and 10). The MLVA was performed in all isolates and clinical samples that retrieved no isolation but presented PCR results.

\subsection{Ethical statement}

The inclusion of all animals in the study was carried out only after owner's consent. This project was approved by the Research Ethics Committee of the University Santo Amaro - (authorization $\mathrm{n}^{\circ}$ 03/2018). All dogs were treated initially with ampicillin (22 mg/Kg; intravenously every $8 \mathrm{~h}$ ), or three doses of penicillin $\mathrm{G}(40,000 \mathrm{U} / \mathrm{kg}$; intramuscularly every $48 \mathrm{~h}$ or $72 \mathrm{~h})$ in a hospital environment.

\section{Results}

Out of the 31 dogs included in the study, 20 (64.5\%) had anti-Leptospira antibodies detectable by MAT, with titers ranging from 100 to 12,800 . Only two dogs were recently vaccinated (19 and 29), but dog 29 had no detectable antibodies. Eleven dogs had acute infection determined by MAT (35.5\%), as shown in Table 1. Ten of them had titers $\geq 800$ in a single serum sample, while serodiagnosis of one dog (dog 10 ) was established by MAT titration of convalescent serum samples, which showed seroconversion against Icterohaemorrhagiae serogroup.

The serological profile of the MAT-confirmed cases showed that the most frequently serogroups found infecting dogs were Autumnalis and Icterohaemorrhagiae ( $n=4$ for each), followed by Canicola $(n=2)$ (Table 1). One animal presented the highest titers against Bratislava and Autumnalis (dog 19), but only titers against Bratislava persisted after serological reevaluation of the convalescent sample. 
Leptospira DNA was detected by PCR in 12 dogs (38.7\%). Five dogs presented DNA only in urine samples, while four dogs presented DNA exclusively in blood samples, and three dogs yielded positive results in both samples. Twelve PCR-positive dogs had infection confirmed by DNA sequencing, and all sequences presented high similarity (>99\%) to L. interrogans representatives (AY996798, AY996800). Species identity was further confirmed by the 16S rRNA phylogenetic analysis, which showed the formation of a cluster with reference sequences of $L$. interrogans (Figure 1). The recovered sequences were submitted to GenBank under accession numbers MW263930 - MW263941.

The comparison between MAT and PCR results showed that five dogs (12, 14, 19, 21 and 23) were diagnosed exclusively by MAT, and six other dogs $(2,4,5,13,16$ and 30$)$ were positive only by PCR, while six animals $(6,8,9,10,25$ and 26$)$ were positive in both tests, totaling 17 dogs with confirmed acute infection.

Leptospires could be recovered from four dogs. Three out of four (Strains 117, 118 and 120, recovered from dogs 4, 5 and 9 respectively) showed a specific reaction against serogroup Icterohaemorrhagiae $(6,400)$ after serogrouping with polyclonal antibodies, while the strain 119 (recovered from dog 6) presented the highest titration against serogroup Canicola $(1,600)$.

The MLVA analysis of the isolates using three discriminatory markers for the VNTR loci 4, 7 and 10 revealed a VNTR 2-1-8 profile in samples taken from dogs 4, 5 and 9, being compatible with the serogroup Icterohaemorrhagiae, and a 1-10-3 VNTR profile for the dog sample 6, compatible with the serogroup Canicola pattern. The MLVA technique was also applied to positive PCR samples in which the recovery of leptospires was not possible, in an attempt to compare the pattern of clinical samples with those found in the isolates; nevertheless, only samples from dogs 13,16 and 30 yielded interpretable profiles, which were compatible with the pattern assigned to the serogroup Icterohaemorrhagiae.

The clinical outcome from 31 dogs could be determined: 6 dogs survived after proper treatment. Death or euthanasia occurred in 21 cases, and the overall lethality among cases with confirmed acute infection was 13. The Outcome could not be determined in 4 cases due to the discontinued follow-up care.

\section{Discussion}

Viable leptospires could be recovered from four dogs with confirmed acute leptospiral infection, and further molecular and serological characterization enabled the identification of $L$. interrogans serogroups Icterohaemorrhagiae (strains 4, 5 and 9) and Canicola (strain 6) as causative agents for canine leptospirosis in the present study.

Despite canine acute infection caused by pathogenic Leptospira being largely reported in Latin America (29), the characterization of the infecting strains at a serovar or serogroup level is restricted to a few studies that have successfully isolated the pathogen in culture media $(5,12,18,19,30-$ 34). In recent years, isolation and proper characterization of the infecting strains in dogs with acute leptospirosis has shown that dogs can be exposed to a wide variety of serogroups (6), depending on the geographical region (e. g. urban or rural settings, tropical or temperate climate), local environmental and behavioral conditions (contact with wildlife fauna, sanitation, restriction of roaming behavior), and implementation of preventive measures against infection (use of vaccines, rodent control policies). Such variety may impose serious challenges to produce effective vaccines containing leptospiral strains circulating locally.

Furthermore, several countries have reported an antigenic shift due the extensive use of vaccines (10), giving rise to serovars not included in traditional vaccine compositions, highlighting the importance of using dogs as sentinels to access strains circulating locally.

Our results corroborate previous serological findings showing that Icterohaemorrhagiae is likely the main causative pathogen for acute canine infection in Brazil $(5,19,35,36)$. These findings are also in agreement with the few studies that have consistently characterized Icterohaemorrhagiae as the main infecting serogroup in symptomatic dogs $(5,19)$, reinforcing the hypothesis that dogs are highly exposed to environmental contamination promoted by rodents.

Serogroup Icterohaemorrhagiae is also considered the main causative agent for human leptospirosis in Brazil, notably in São Paulo city (37,38). The UNISA veterinary hospital is located at the south area of São Paulo, a region with the highest incidence rates for human leptospirosis, with an annual average of 57 reported human cases of leptospirosis between 2017 and 2019 (39). The area is characterized by having the highest precipitation rates in the city (40), with many humans living in low-income communities with poor sanitation, which can predispose not only humans, but also dogs to environmental exposure to pathogenic Leptospira spp. Under such conditions, dogs can act as important sentinels (41), and the diagnosis of acute canine infection and further characterization of the infecting Leptospira spp. may assist local health authorities to prevent leptospiral transmission by mitigating risk factors shared both by humans and dogs. Moreover, most districts in the area have a rural-urban interface configuration, with intense wildlife fauna interaction, which can lead to the transmission of leptospires maintained by wild reservoirs, reinforcing the importance of implementing local epidemiological surveillance using dogs as sentinels. In fact, a recent serological survey conducted by Diodato et al. (2016)(42) have found that Autumnalis is the most frequently serogroup found in asymptomatic semi-domiciled and stray dog populations from the south area of São Paulo. Interestingly, even in face of the successful characterization of Icterohaemorrhagiae and Canicola isolates in the present study, several dogs with acute infection confirmed by MAT presented the highest titers against Autumnalis serogroup. 
Acute infection caused by Autumnalis was recently reported in humans and dogs from Japan(43), thus indicating a possible zoonotic transmission of this particular serogroup. In Latin America, serological surveys conducted in the islands of Barbados (44), Saint Kitts (45) and Trinidad (46) have also found Autumnalis as the predominant serogroup among dogs, and the isolation of serovar Bim (serogroup Autumnalis) from an asymptomatic carrier dog have also been described (31).

In Brazil, Autumnalis was identified as the main infecting serogroup found in stray and asymptomatic dog populations from different parts of the country (47-55), however confirmation of infection by isolation and molecular/serological characterization hasn't been described yet.

Unfortunately, isolation was not achieved in samples taken from dogs presenting the highest titers against Autumnalis in the present study, and the actual infecting serogroup attributed to those cases could not be determined. The MLVA analysis have also failed to identify serogroup identity in these samples, and despite $L$. interrogans infection was confirmed by 16 SrRNA sequencing analysis, molecular typing methods using single-gene sequencing have poor discriminatory power to identify leptospires at a serovar/serogroup level. Therefore, serological evidence of Autumnalis infection should be interpreted with caution, as MAT results might have a low correlation with the actual infecting serogroup due to cross-reaction between serovars $(56,57)$, especially in acute cases, where paradoxical reaction is common. Moreover, cross-reactions between serogroup Icterohaemorrhagiae and Autumnalis have been described after natural infection by Icterohaemorrhagiae serogroup (58), and the use of commercial vaccines containing Icterohaemorrhagiae representatives may also potentially induce cross-reactions between both serogroups $(50,59)$.

In the present study, the association of PCR and MAT tests allowed the diagnosis of leptospirosis in 17 of the 31 dogs included in the study (54.8\%), demonstrating that part of these animals would have had a false-negative result if only one of the tests had been performed. Despite the benefits of associating both tests for the diagnosis of acute canine leptospirosis, the PCR was able to diagnose more infected dogs when used as a single strategy, thus indicating the benefits of this method for the definitive diagnosis at the early stages of the disease, as previously reported $(5,60)$.

The PCR results from 12 positive samples were confirmed by sequencing and phylogenetic analysis, and all sequences clustered with sequences belonging to $L$. interrogans representatives. This approach has allowed the identification of unexpected leptospires infecting dogs in Brazil, such as L. santarosai (5), L. kirchnneri (61) and L. noguchii (21), evidencing that this approach could be useful to circumvent the role of dogs in the transmission chain of leptospirosis.

The MLVA analysis have confirmed species identity of the isolates, with $100 \%$ agreement with MAT using polyclonal antibodies. This molecular technique has been successfully used to identify particular serogroups in clinical samples in which isolation could not be achieved (62). In the present study, most samples with presenting leptospiral DNA confirmed by the 16SrRNA PCR protocol have not yielded MLVA Positive results, probably due to the insufficient DNA concentration. Nevertheless, MLVA was able to identify infection by serogroup Icterohaemorrhagiae in two dogs with no MAT titers, and the application of this technique should be incorporated in future studies tackling canine acute leptospiral infection.

Despite the usefulness of molecular methods for the diagnosis of acute leptospirosis, the use of PCR may lead to false positive results in cases where non-leptospiral diseases mimicking acute leptospirosis are concomitantly present in dogs presenting chronic urinary shedding of leptospires. Moreover, no proper comparison between MAT and PCR results could be performed in consequence of the high lethality of the disease, which hampered the evaluation of MAT convalescent titers in most dogs.

The lethality was strikingly high among the suspected cases studied (67.7\%), reinforcing previous studies from our group (5). These findings highlight the urgent need for implementing new therapeutic strategies in canine leptospirosis, as observed in clinical trials with human subjects (63). Additionally, the high proportion of dogs with no confirmation of infection reveals that investigation of other causes leading to clinical signs similar to acute leptospirosis should be investigated, and that the current diagnostic strategies should be improved for the diagnosis of the disease.

\section{Conclusion}

Our results have demonstrated that dogs from the south of São Paulo are being exposed to serogroup Icterohaemorrhagiae and possibly serogroup Autumnalis. These findings reinforce the importance of vaccination against leptospirosis in the region, highlighting also that the identification of leptospires infecting symptomatic dogs may help estimate which are strains circulating locally. Epidemiological surveillance using dogs as sentinels should be a continuous effort, and future studies regarding the epidemiological aspects of leptospirosis are needed to fully circumvent key aspects of canine leptospirosis.

\section{Abbreviations}

EDTA: Ethylenediamine tetraacetic acid; EMJH: Ellinghausen McCullough Johnson Harris MAT: Microscopic agglutination test; MLST: Multilocus Sequence Typing; MVLA: Multiple locus variable-number tandem repeat analysis; PCR: Polymerase Chain Reaction; VNTR: Variable number tandem repeat. 


\section{Declarations}

All methods were carried out in accordance with relevant guidelines and regulations.

\section{Ethics approval and consent to participate}

This project was approved by the Research Ethics Committee of the University Santo Amaro - (authorization $\mathrm{n}^{\circ} 03 / 2018$ ). Informed consent was obtained from owners.

\section{Consent for Publication}

Not applicable.

\section{Availability of data and materials}

All data generated or analysed during this study are included in this published article.

\section{Competing interests}

The authors declare that they have no competing interests.

\section{Funding}

This research did not receive any specific grant from funding agencies in the public, commercial, or not-for-profit sectors.

\section{Author's contributions}

CMS, BAM, APG, GCDRSD, AVPS and AC made substantial contributions to the conception of the study design, acquisition, analysis and interpretation of data; SBE, MBH and IBG contributed to the data analysis and by revising it critically for important intellectual content; Each author have participated sufficiently in the work to take public responsibility for appropriate portions of the content; CMS, BAM and APG agreed to be accountable for all aspects of the work in ensuring that questions related to the accuracy or integrity of any part of the work are appropriately investigated and resolved. All authors read and approved the final manuscript.

\section{Acknowledgements}

The authors are grateful to HOVET-UNISA staff, Bianca Caroline Souza Silva, Hedillon Mattos and Sandro Scherer.

\section{References}

1. Bowser NH, Anderson NE. Dogs (Canis familiaris) as sentinels for human infectious disease and application to Canadian populations: A systematic review. Vet Sci. 2018;5(4).

2. Munoz-Zanzi C, Groene E, Morawski B, Bonner K, Costa F, Bertherat E, et al. A systematic literature review of leptospirosis outbreaks worldwide, 1970-2012. Rev Panam Salud Pública. 2020;44(July):1.

3. Goldstein RE. Canine Leptospirosis. Vet Clin North Am Small Anim Pract. 2010 Nov;40(6):1091-101.

4. Ricardo T, Previtali MA, Signorini M. Meta-analysis of risk factors for canine leptospirosis. Prev Vet Med . 2020 Aug;181:105037. https://doi.org/10.1016/j.prevetmed.2020.105037

5. Miotto BA, Tozzi BF, Penteado M de S, Guilloux AGA, Moreno LZ, Heinemann MB, et al. Diagnosis of acute canine leptospirosis using multiple laboratory tests and characterization of the isolated strains. BMC Vet Res. 2018;14(1):222.

6. Schuller S, Francey T, Hartmann K, Hugonnard M, Kohn B, Nally JE. European consensus statement on leptospirosis in dogs and cats. J Small Anim Pract. 2015;56(3):159-79.

7. Adler B, de la Peña Moctezuma A. Leptospira and leptospirosis. Vet Microbio. 2010 Jan;140(3-4):287-96.

8. Fink JM, Moore GE, Landau R, Vemulapalli R. Evaluation of three 5' exonuclease-based real-time polymerase chain reaction assays for detection of pathogenic Leptospira species in canine urine. J Vet Diagnostic Investig. 2015;27(2):159-66.

9. Harkin KR, Roshto YM, Sullivan JT. Clinical application of a polymerase chain reaction assay for diagnosis of leptospirosis in dogs. J Am Vet Med Assoc. 2003 May;222(9):1224-9.

10. Bertasio C, Boniotti MB, Lucchese L, Ceglie L, Bellinati L, Mazzucato M, et al. Detection of New Leptospira Genotypes Infecting Symptomatic Dogs: Is a New Vaccine Formulation Needed? Pathogens. 2020;9:484.

11. Fraune CK, Schweighauser A, Francey T. Evaluation of the diagnostic value of serologic microagglutination testing and a polymerase chain reaction assay for diagnosis of acute leptospirosis in dogs in a referral center. J Am Vet Med Assoc. 2013 May 15;242(10):1373-80. 
12. Loffler SG, Passaro D, Samartino L, Soncini A, Romero G, Brihuega B. Genotypes of Leptospira spp. strains isolated from dogs in Buenos Aires, Argentina. Rev Argent Microbiol. 2014 Jul;46(3):201-4.

13. Koizumi N, Muto MM, Izumiya H, Suzuki M, Ohnishi M. Multiple-locus variable-number tandem repeat analysis and clinical characterization of Leptospira interrogans canine isolates. J Med Microbiol. 2015;64(3):288-94.

14. Nielsen JN, Cochran GK, Cassells JA, Hanson LE. Leptospira interrogans serovar bratislava infection in two dogs. Vol. 199, Journal of the American Veterinary Medical Association. 1991. p. 351-2.

15. Paungpin W, Chaiwattanarungruengpaisan S, Mongkolphan C, Wiriyarat W, Thongdee M. Genotyping of the causative Leptospira in symptomatic dogs in Thailand. Korean J Vet Res. 2020;60(1):1-7.

16. Cole JR, Sangster LT, Sulzer CR, Pursell AR, Ellinghausen HC. Infections with Encephalitozoon cuniculi and Leptospira interrogans, serovars grippotyphosa and ballum, in a kennel of Foxhounds. J Am Vet Med Assoc. 1982;180(4):435-7.

17. Jorge S, Monte LG, De Oliveira NR, Collares TF, Roloff BC, Gomes CK, et al. Phenotypic and molecular characterization of Leptospira interrogans isolated from canis familiaris in Southern Brazil. Curr Microbiol. 2015;71(4):496-500.

18. Miraglia F, de Morais ZM, Dellagostin OA, Seixas FK, Freitas JC, Zacarias FGS, et al. Molecular and serological characterization of Leptospira interrogans serovar canicola isolated from dogs, swine, and bovine in Brazil. Trop Anim Health Prod. 2012;45(1):117-21.

19. Rodrigues AMA, Hagiwara MK, Moraes ZM, Souza GO, Gonçales AP, Silva AQ, et al. Isolation and Chacacterization of Leptospira interrogans serovar Copenhageni and Serovar Canicola from Dogs with Leptospirosis. J Vet Intern Med. 2012;26:791.

20. Scandura SC, Saldanha AVP, Hernandez FA da S, Heinemann MB, Gonçales AP. Pesquisa sorológica de sorovares de leptospiras que mais frequentemente infectam e causam doença em cães com suspeita clínica de leptospirose. Brazilian J Dev. 2020;6(2):9391-403.

21. Silva EF, Cerqueira GM, Seyffert N, Seixas FK, Hartwig DD, Athanazio DA, et al. Leptospira noguchii and human and animal leptospirosis, Southern Brazil. Emerg Infect Dis. 2009;15(4):621-3. https://dx.doi.org/10.3201/eid1504.071669

22. Prefeitura de São Paulo, IBGE. População recenseada, projetada, taxas de crescimento populacional e densidade demográfica do município de São Paulo, subprefeituras e distritos municipais. 2010.

https://www.prefeitura.sp.gov.br/cidade/secretarias/urbanismo/dados_estatisticos/info_cidade/index.php/. Accessed 12 Nov 2020.

23. Faine S, Adler B, Bolin C, Perolat P. Leptospira and Leptospirosis (2nd edition). Book, MedSci, Armadale, Australia. 1999.

24. Mérien F, Amouriaux P, Perolat P, Baranton G, Girons IS. Polymerase chain reaction for detection of Leptospira spp. in clinical samples. J Clin Microbiol. 1992;30(9):2219-24.

25. Dikken H, Kmety E. Chapter VIII: Serological Typing Methods of Leptospires. In: Methods in Microbiology. 1978. p. $259-307$.

26. Togawa RC, Brigido MM. PHPH: Web based tool for simple electropherogram quality analysis. In: 1st International Conference on Bioinformatics and Computational Biology - ICoBiCoBi. Ribeirão Preto - SP. 2003.

27. Kumar S, Stecher G, Tamura K. MEGA7: Molecular Evolutionary Genetics Analysis Version 7.0 for Bigger Datasets. Mol Biol Evol. 2016 Jul;33(7):1870-4.

28. Salaün L, Mérien F, Gurianova S, Baranton G, Picardeau M. Application of multilocus variable-number tandem-repeat analysis for molecular typing of the agent of leptospirosis. J Clin Microbiol. 2006;44(11):3954-62.

29. Azócar-Aedo L, Monti G. Meta-Analyses of Factors Associated with Leptospirosis in Domestic Dogs. Zoonoses Public Health. 2016;63(4):32836.

30. Fiorello C V., Straub MH, Schwartz LM, Liu J, Campbell A, Kownacki AK, et al. Multiple-host pathogens in domestic hunting dogs in Nicaragua's Bosawás Biosphere Reserve. Acta Trop. 2017 Mar;167:183-90. Available from: http://dx.doi.org/10.1016/j.actatropica.2016.12.020

31. Jones CJ, Sulzer KR, Everard CO, Vaughn AW, Innis VA. Bim, a new serovar of Leptospira interrogans isolated from a dog in Barbados. J Clin Microbiol. 1984;19(6):946.

32. Larson CR, Dennis M, Nair R V., Llanes A, Peda A, Welcome S, et al. Isolation and characterization of Leptospira interrogans serovar Copenhageni from a dog from Saint Kitts. JMM Case Reports. 2017;4(10):1-5.

33. Peláez Sanchez RG, Lopez JÁ, Pereira MM, Naranjo MA, Agudelo-F Lórez P. Genetic diversity of leptospira in northwestern Colombia: First report of Leptospira santarosai as a recognised leptospirosis agent. Mem Inst Oswaldo Cruz. 2016;111(12):737-44.

34. Suepaul SM, Carrington CVF, Campbell M, Borde G, Adesiyun AA. Serovars of Leptospira isolated from dogs and rodents. Epidemiol Infect. 2010;138(7):1059-70.

35. Freire IMA, Varges RG, Gomes YNP, Pombo CR, Lilenbaum W. Distribuição dos serovares de Leptospira em caninos clinicamente suspeitos no Rio de Janeiro. Rev Bras Ciência Veterinária. 2007;14(2):83-5.

36. Querino AMV, Delbem ÁCB, Oliveira RC de, Silva FG da, Müller EE, Freire RL, et al. Fatores de risco associados à leptospirose em cães do município de Londrina-PR. Semin Ciências Agrárias. 2003 May 10;24(1):27.

37. Blanco RM, Romero EC. Fifteen years of human leptospirosis in São Paulo, Brazil. J Epidemiol Res. 2015 Oct 18;2(1):56. 
38. Romero EC, Bernardo CC da M, Yasuda PH. Human leptospirosis: a twenty-nine-year serological study in São Paulo, Brazil. Rev Inst Med Trop Sao Paulo. 2003;45(5):245-8.

39. Estado de São Paulo. Alerta para maior risco de Leptospirose na estação chuvosa 2019/2020 - CRS Sul. São Paulo, 2020. Coordenadoria de Vigilância em Saúde, Prefeitura de São Paulo. 2020.

https://www.prefeitura.sp.gov.br/cidade/secretarias/upload/saude/alerta_leptospirose_sul_2020.pdf Accessed 03 Nov 2020.

40. Marcuzzo FFN. A distribuição espacial da chuva mensal e anual no território do Município de São Paulo. In: $27^{\circ}$ Encontro técnico AESabesp Congresso Nacional de Saneamento e Meio Ambiente. São Paulo; 2016.

41. Bowser N, Anderson N. Dogs (Canis familiaris) as Sentinels for Human Infectious Disease and Application to Canadian Populations: A Systematic Review. Vet Sci. 2018 Sep 21;5(4):83.

42. Diodato, R. V. NARIMATSU JT, Pedro NHG, Nakata TB, Agopian RG, Gonçales AP. Prevalência e Fatores de Risco Associado à Leptospirose Canina no Extremo Sul do Municipio de São Paulo. In: $19^{\circ}$ Congresso de Iniciação Científica e 13ª Mostra de Pós-graduação. São Paulo; 2016.

43. Koizumi N, Izumiya H, Ohnishi M. Genetic relatedness of Leptospira interrogans serogroup Autumnalis isolated from humans, dogs, and mice in Japan. BMC Res Notes. 2020;13(1):1-4. https://doi.org/10.1186/s13104-020-05211-1

44. Weekes CC, Everard CO, Levett PN. Seroepidemiology of canine leptospirosis on the island of Barbados. Vet Microbiol. 1997;57(2-3):215-22. A

45. Pratt N, Conan A, Rajeev S. Leptospira Seroprevalence in Domestic Dogs and Cats on the Caribbean Island of Saint Kitts. Vet Med Int. 2017;2017:1-6.

46. Adesiyun AA, Hull-Jackson C, Mootoo N, Halsall S, Bennett R, Clarke NR, et al. Sero-epidemiology of Canine Leptospirosis in Trinidad: Serovars, Implications for Vaccination and Public Health. J Vet Med. 2006;53:91-9.

47. Aguiar DM, Cavalcante GT, Marvulo MF V, Silva JTR, Pinter A, Vasconcellos SA, et al. Fatores De Risco Associados À Ocorrência De Anticorpos Anti-Leptospira Spp. Em Cães Do Município De Monte Negro, Rondônia, Amazônia Ocidental Brasileira. Arq Bras Med Vet Zootec. 2007;59:706.

48. Alves CJ, Andrade JSL de, Vasconcellos SA, Morais ZM de, Azevedo SS de, Santos FA dos. Avaliação dos níveis de aglutininas anti-leptospira em cães no município de Patos- PB, Brasil. Rev Bras Ciência Veterinária. 2000;7(1):17-21.

49. Batista C de SA, Azevedo SS de, Alves CJ, Vasconcellos SA, Morais ZM de, Clementino IJ, et al. Soroprevalência de leptospirose em cães errantes da cidade de Patos, Estado da Paraíba, Brasil. Brazilian J Vet Res Anim Sci. 2004 Apr;41(2):131-6.

50. Castro JR de, Salaberry SRS, Souza MA de, Lima-Ribeiro AMC. Sorovares de Leptospira spp. predominantes em exames sorológicos de caninos e humanos no município de Uberlândia, Estado de Minas Gerais. Rev Soc Bras Med Trop. 2011 Apr 1;44(2):217-22.

51. de Azevedo SS, Fernandes ARF, Queiroga IMBN, Alves CJ, de Morais ZM, Santos CDSAB, et al. Ocorrência e fatores de risco associados à leptospirose em cães atendidos em hospital veterinário no semiárido paraibano. Braz J Vet Res Anim Sci. 2011;48(2):161-6.

52. Langoni H, Silva AV da, Segismundo R, Lucheis SB, Paes AC. Variáveis epidemiológicas e alterações clínicas, hematológicas e urinárias em cães sororreagentes para Leptospira spp. Semin Ciências Agrárias. 2013; 34(2):765-76.

53. Lemos JP, Melo CB de, Viegas SAR de A. Análise Sorológica De Leptospira Spp. Em Cães Errantes No Município De Aracaju. Rev Científica eEetrônica Med Veterinária. 2010;8(14).

54. Lobo EA, Tautz SM, Charlier CF, Conceição A da, Pires Neto JAS. Estudo Comparativo do Padrão Sorológico de Animais Domésticos Potencialmente Transmissores de Leptospirose no Município de Santa Cruz do Sul, RS, Brasil, entre os anos 2002 e 2003. Cad Pesqui Sér Bio [Internet]. 2004;16(2):47-64.

55. Oliveira LA de, Zaniolo MM, Dias EH, Brandão HBS, Rubio KAJ, Ferreira BPM, et al. Leptospirosis and brucellosis seroepidemiology in sheep and dogs from non-mechanized rural properties in the northwestern region in the state of Paraná. Semin Ciências Agrárias. 2016; 37(5):3147.

56. Levett PN. Usefulness of Serologic Analysis as a Predictor of the Infecting Serovar in Patients with Severe Leptospirosis. Clin Infect Dis. 2003; 36(4):447-52.

57. Smythe LD, Wuthiekanun V, Suputtamongkol Y, Tiengrim S, Dohnt MF, Symonds ML, et al. The Microscopic Agglutination Test (MAT) Is an Unreliable Predictor of Infecting Leptospira Serovar in Thailand. Am J Trop Med Hyg. 2009;81(4):695-7.

58. Blanco RM, dos Santos LF, Galloway RL, Romero EC. Is the microagglutination test (MAT) good for predicting the infecting serogroup for leptospirosis in Brazil? Comp Immunol Microbiol Infect Dis. 2016 Feb;44(1):34-6.

59. Midence JN, Leutenegger CM, Chandler AM, Goldstein RE. Effects of Recent Leptospira Vaccination on Whole Blood Real-Time PCR Testing in Healthy Client-Owned Dogs. J Vet Intern Med. 2012 Jan 1;26(1):149-52.

60. Harkin KR, Roshto YM, Sullivan JT, Purvis TJ, Chengappa MM. Comparison of polymerase chain reaction assay, bacteriologic culture, and serologic testing in assessment of prevalence of urinary shedding of leptospires in dogs. Javma. 2003;222(9).

61. da Cunha CEP, Felix SR, Seixas Neto ACP, Campello-Felix A, Kremer FS, Monte LG, et al. Infection with Leptospira kirschneri Serovar Mozdok: First Report from the Southern Hemisphere. Am J Trop Med Hyg. 2016; 94(3):519-21. 
62. Pailhoriès H, Buzelé R, Picardeau M, Robert S, Mercier E, Mereghetti L, et al. Molecular characterization of Leptospira sp by multilocus variable number tandem repeat analysis (MLVA) from clinical samples: a case report. Int J Infect Dis. 2015; 37:119-21.

http://dx.doi.org/10.1016/j.ijid.2015.06.026

63. Naing C, Reid SA, Aung K. Comparing antibiotic treatment for leptospirosis using network meta-analysis: a tutorial. BMC Infect Dis]. 2017;17(1):29. Available from: http://dx.doi.org/10.1186/s12879-016-2145-3

\section{Table}


Table 1

PCR results, MAT titers and immunization records found in 31 dogs suspected of acute leptospirosis.

\begin{tabular}{|c|c|c|c|c|c|c|c|c|c|c|c|c|c|c|c|}
\hline \multirow{2}{*}{$\begin{array}{l}\text { Dog } \\
\text { ID }\end{array}$} & \multirow{2}{*}{$\begin{array}{l}\text { Blood } \\
\text { PCR }\end{array}$} & \multirow{2}{*}{$\begin{array}{l}\text { Urine } \\
\text { PCR }\end{array}$} & \multirow{2}{*}{$\begin{array}{l}\text { MAT- } \\
\text { confirmed } \\
\text { cases }\end{array}$} & \multirow{2}{*}{$\begin{array}{l}\text { Vaccination } \\
\text { (<1 year) }\end{array}$} & \multicolumn{11}{|c|}{ Serogroups and respective titer found in MAT } \\
\hline & & & & & AUS & AUT & CAS & BAT & CAN & CYN & GRY & ICT & POM & PYR & SHE \\
\hline 1 & - & NP & - & - & - & - & - & - & - & - & - & - & - & - & - \\
\hline 2 & $(+)$ & $(+)$ & - & - & - & - & - & - & - & - & - & 200 & - & - & - \\
\hline 3 & - & - & - & - & - & - & - & - & 100 & - & - & - & - & - & - \\
\hline 4 & $(+)$ & $(+)$ & - & - & - & - & - & - & - & - & - & - & - & - & - \\
\hline 5 & $(+)$ & NP & - & - & - & - & - & - & - & - & - & - & - & - & - \\
\hline 6 & - & $(+)$ & $(+)$ & - & - & 800 & 1600 & - & 3200 & - & - & 200 & - & - & 200 \\
\hline 7 & - & - & - & - & - & - & - & - & - & - & - & - & - & - & - \\
\hline *7 & NP & NP & - & & - & - & - & - & - & - & - & - & - & - & - \\
\hline 8 & $(+)$ & NP & $(+)$ & - & - & 800 & - & - & - & 200 & - & 200 & - & - & 200 \\
\hline 9 & $(+)$ & $(+)$ & $(+)$ & - & - & 400 & - & - & - & - & - & 800 & - & - & 200 \\
\hline 10 & - & $(+)$ & $(+)$ & - & - & - & - & - & - & - & - & - & - & - & - \\
\hline *10 & NP & $\mathrm{NP}$ & - & & 800 & 800 & 100 & - & 200 & 200 & - & 12800 & 1600 & - & 6400 \\
\hline 11 & - & - & - & - & - & 200 & - & - & - & - & - & 400 & - & - & 400 \\
\hline 12 & - & - & $(+)$ & - & - & - & - & - & 800 & - & - & - & - & 400 & - \\
\hline 13 & $(+)$ & NP & - & - & - & - & - & - & - & - & - & - & - & - & - \\
\hline 14 & - & - & $(+)$ & - & - & 200 & - & - & - & - & - & 12800 & - & - & 6400 \\
\hline 15 & - & NP & - & - & - & - & - & - & - & - & - & 100 & - & - & - \\
\hline 16 & $(+)$ & - & - & - & - & 100 & - & - & - & - & - & 400 & - & - & - \\
\hline 17 & - & - & - & - & - & - & - & - & - & - & - & 200 & - & - & 200 \\
\hline 18 & - & - & - & - & - & - & - & - & - & - & - & 100 & - & - & 100 \\
\hline 19 & - & - & $(+)$ & $(+)$ & 1600 & 1600 & - & 800 & - & - & - & 800 & - & - & 800 \\
\hline *19 & NP & NP & - & & 400 & - & - & - & - & - & - & 200 & - & - & - \\
\hline 20 & - & - & - & - & - & - & - & - & - & - & - & - & - & - & - \\
\hline 21 & - & - & $(+)$ & - & 400 & - & - & - & 200 & - & - & 800 & - & - & 400 \\
\hline 22 & - & - & - & - & - & - & - & - & - & - & - & - & - & - & - \\
\hline 23 & - & - & $(+)$ & - & 400 & 3200 & - & - & 1600 & - & 1600 & 400 & - & - & - \\
\hline 24 & - & - & - & - & - & - & - & - & - & - & - & 100 & - & - & - \\
\hline 25 & - & $(+)$ & $(+)$ & - & - & 800 & - & - & - & - & - & 200 & - & - & - \\
\hline 26 & - & $(+)$ & $(+)$ & - & - & 800 & - & - & - & - & - & - & - & - & - \\
\hline 27 & - & - & - & - & - & - & - & - & - & - & - & - & - & - & - \\
\hline 28 & - & - & - & - & - & 100 & - & - & - & - & - & 200 & - & - & - \\
\hline *28 & NP & NP & - & & - & - & - & - & - & - & - & 100 & - & - & - \\
\hline 29 & - & - & - & $(+)$ & - & - & - & - & - & - & - & - & - & - & - \\
\hline 30 & - & $(+)$ & - & - & - & - & - & - & - & - & - & - & - & - & - \\
\hline 31 & - & $\mathrm{NP}$ & - & - & - & - & - & - & - & - & - & - & - & - & - \\
\hline
\end{tabular}


Figures

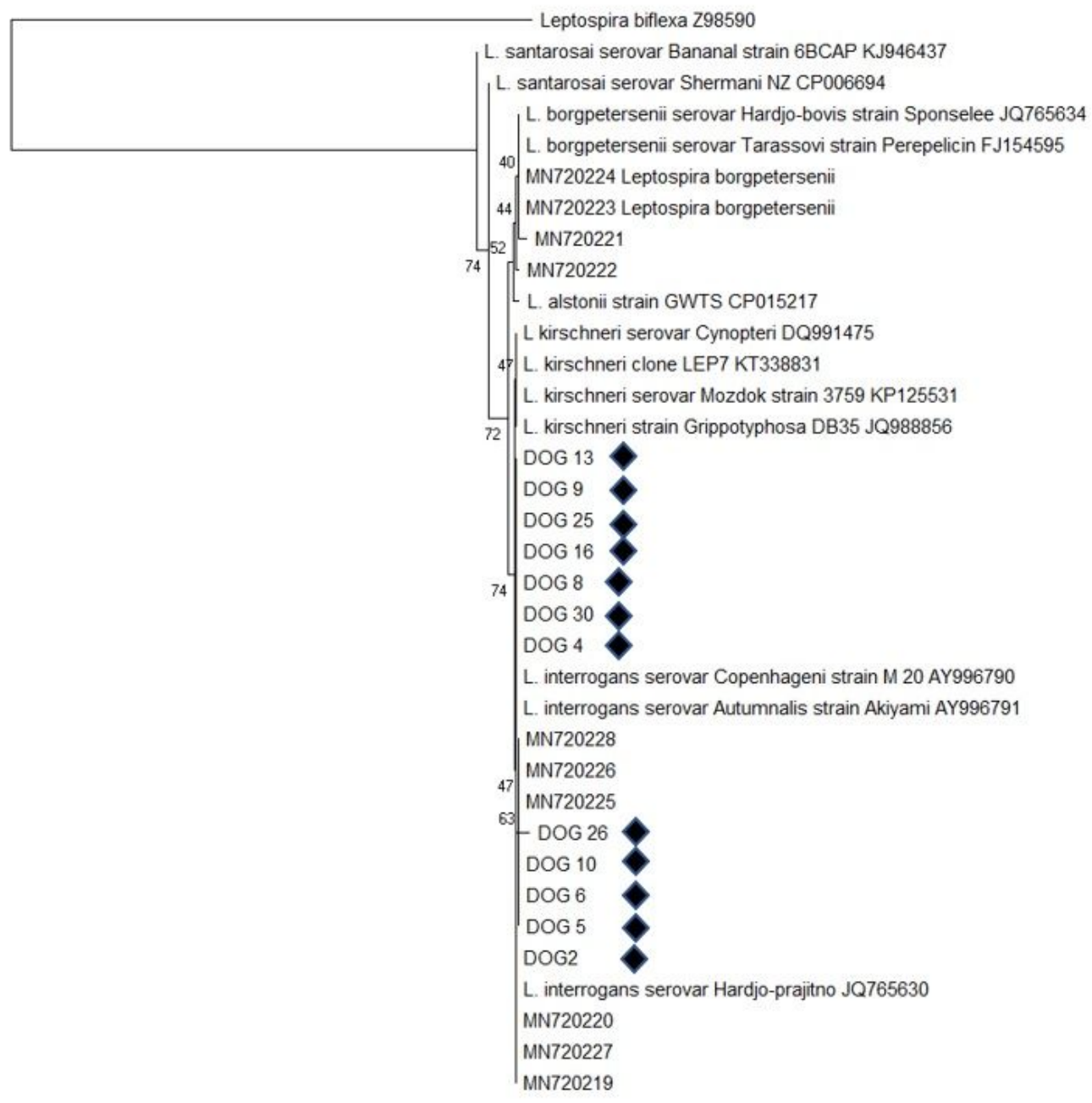

0.10

\section{Figure 1}

Phylogenetic reconstruction based on partial ribosomal 16S gene sequences of reference strains of Leptospira spp. and sequences obtained from dogs with clinical suspicion of acute leptospiral (black diamond). The tree was constructed with the Neighbor-Joining method using Tamura-3 parameter model with bootstrap test of 1,000 replicates. 